Communication Booknotes Quarterly. 2003, v. 34, n.2, p. 78-88.

ISSN: 1094-8007 (Print), 1532-6896 (Online)

DOI:10.1207/S15326896CBQ3402_1

http://www.tandfonline.com/loi/hcbq20

http://www.tandf.co.uk/journals/titles/10948007.asp

(C) 2003 Routlege, Taylor and Francis.

\title{
1. CBQ REVIEW ESSAY: Islam, Arabs, the Middle East and the Media: A Review of Recent Journalism and Broadcast Publications, 1995-2002
}

\section{Eleanor Block (The Ohio State University)}

Ever since the catastrophic events occurring on September 11, 2001, there has been an intense focus on the most relevant question - why? In journalistic terms we know the who, the when, where, and the how but pundits, scholars, politicians, survivors, and indeed, most ordinary citizens around the globe are still left pondering this question. This issue has been explored in countless newspaper and magazine articles, books, and by talking heads on similarly numerous cable and broadcast programs from religious, cultural, political, social, and other contexts. Both reasoned and not so reasoned responses have been offered including those who ask us to understand that the Islamic people, i.e. the proverbial "street" hate the west, Americans, the Europeans, etc. while others plausibly argue differently.

Clearly, the sheer bulk of the written analysis and argument is beyond the purview of this literature review. Instead, this review essay focuses on the topic of the role and use of the media in both the west and in Muslim countries and in an analysis of books and periodicals that investigate this theme. The pervading motif throughout the following 20 monographic publications is that journalists and broadcasters are biased. Note, however, that this is said about both the Islamic and the western press. Each generally sees the other as the biased source.

Included are monographic works devoted exclusively to media, the followers of Islam, the Middle East as a geo-political locale, and Arabs. The review is not confined to Arabs alone (who make up only a fraction of Muslims), nor is it confined geographically to the Middle East alone since Muslims live throughout the world. Among the media discussed here are newspapers, magazines, and broadcast media. Other media including the Internet, cell phones, satellites, personal computers, and the like have been omitted due to space. While many of the society and organization publications are brief, they have been included due to their relevance. The entries are arranged alphabetically by author, as is usual for $C B Q$. Most of the literature cited is scholarly in nature, while others represent opinion or other non-scholarly types of works. In addition to works specifically on various media, other books focus on such topics as advice on how to provide good coverage, the history of the press, and journalist narratives.

The author regrets her inability to read and understand other languages, particularly Arabic, since many very appropriate materials located via WorldCat in Arabic and other languages, particularly German and French, might have provided a broader look at this topic. Works in other languages other than English certainly would have enhanced the differences in opinion and provided a more international scope. Although the seminal date around which this material is concentrated is September 11, 2001, all the publications cited date from 1995 through 2002. The 1995 beginning date is somewhat arbitrary, however, in that the goal of this review is to provide the most up-to-date materials on the subject. 
Two important caveats. First, while one hopes to create a well-balanced critique and a list of mostly well-balanced titles, many of the following cannot be said to fall in this category at all. Due to the nature of the topic, around which great and often emotional controversy swirls, this cannot be entirely unexpected. Scholars, librarians, and their patrons should expect and value widely divergent opinions and perspectives. Each author and editor is convinced that his view is the correct one. It is not the role of this reviewer to say who is right and who is wrong but to convey the content and usefulness of their written words. Second, although Israelis and Israel are mentioned frequently throughout a great number of the entries and when appropriate are mentioned in this review, no publications devoted wholly to the Israeli media unless about other regional media as well are included in order to have a more definitive focus on Arabs and Islam.

\section{4:150}

\section{THE ISRAELI-EGYPTIAN PEACE PROCESS IN THE REPORTING OF WESTERN} JOURNALISTS by Muhammad ibn Abd al-Ghani Nawawi (Westport: Ablex "Civic Discourse for the Third Millennium," 2002-\$66.95/24.95, ISBN 1-56750-544-9 hard, 1-56750-545-7 paper, 214 pp., appendices, references, tables, index) is an interesting attempt to place a different spin on the Israeli-Egyptian peace process. The book's purpose is to "provide information on how and why news about the Middle East conflict in general and the Israeli-Egyptian relationship in particular comes to be shaped and presented not only in the U.S. news media but also in the Western news media in general." Rather than books written from the usual historical, regional, political, or religious perspective, the author reveals a somewhat different perspective, that is, the experiences and views of western correspondents operating in Israel and in Egypt. He bases his research on the results of a survey conducted in autumn 1998. Western journalists are defined here as those from North America, Central and Western Europe, and Australia. Each of the journalists, interviewed by the author, is stationed in the Middle East and whose primary responsibility is to report to an international audience. In all, 168 correspondents participated, 94 in Israel and 74 in Egypt. As noted, this represented about $88 \%$ of the total of foreign correspondents in the Middle East at the time so this in itself is a fairly remarkable achievement. The findings are divided into 15 chapters that begin by presenting an historical overview of the situation both before and after the Oslo Accords. He then tries to compare the Israeli and Egyptian cultures and his own background. The bulk of the book is devoted to both an explanation of the interview process and chapters devoted to government and media relationships and censorship in Egypt and Israel arranged in such models as the news making model and the public relations asymmetric model. The three appendices include a detailed chart revealing the demographic backgrounds of the western correspondents, a copy of the actual questionnaire, and finally, a list of terms and definitions used in the survey. Born in Egypt, the author is an assistant professor of journalism at the University of West Florida. This work represents very scholarly research that is interesting and easy to understand accompanied by a useful nine-page bibliography of English language sources.

\section{4:151}

THE PRESS IN THE ARAB MIDDLE EAST: A HISTORY by Ami Ayalon (New York: Oxford University Press "Studies in Middle Eastern History," 1995 — \$75.00, ISBN 0-19-508780-1, 300 pp., notes, references, notes) offers an historical and contemporary review of the press in the Arab Middle East (excluding, of course, Israel), divided into two parts: historical phases and aspects of development. Each of these parts is subsequently divided into four and five chapters. Ayalon provides the main aspects of the evolution of the Arabian press between the early 
1800's and 1945. He begins with the earliest Ottoman presses and follows with chapters that offer background and analysis of the press in Lebanon, Egypt, Syria, Iraq, and Palestine. These chapters are arranged primarily by time periods: before $1855,1855-1882,1882-1918$, and 1918-1945. The text throughout is devoted to the written press, not broadcast media. Part II delves into such issues as freedom of the press, readership, enhancing the professionalism of Arab journalists, and challenges to the development of a contemporary press. In addition to the continual and important references to the significant relationship of state and the press, the author does offer his take on the current state of the Arab journalism and journalists. Thus, it is interesting to note an entire chapter, "The Economic Angle: The Press as Merchandise and Enterprise," that, among other topics, presents information on three potential and real sources of income: advertising, circulation, and subsidization. The monograph was published in cooperation with The Moshe Dayan Center for Middle Eastern and African Studies. Author Ayalon is chair and associate professor of the department of Middle Eastern and African History at Tel Aviv University. The historical research and other supportive documentation are evidence of serious scholarship and study. For all communication collections.

\section{$34: 152$}

BROADCASTING IN THE ARAB WORLD: A SURVEY OF THE ELECTRONIC MEDIA IN THE MIDDLE EAST by Douglas A. Boyd. (Ames: Iowa State University Press, 1999 [3rd. ed.] — \$72.95, ISBN 0-8138-0467-1, 401 pp., tables, notes, bibliography, index) provides a depth of information about the political and historical development of television and radio in the Arab world. The primary arrangement is geographical. The text is divided into five parts. Except for the introductory first part, the book is divided into geographic chapters arranged in separate chapters devoted to one country or geographical area. Parts 2 through 5 cover national systems, the gulf states, North Africa, and international broadcasting in Arabic. In all, there are 23 chapters on such countries as Egypt, West Bank and Gaza, Kuwait, United Arab Emirates, Algeria, and many other locales. Thus, the Arab world is defined here as both the traditional Arabic-speaking countries and North Africa. For this reason, Turkey, Iran, Cyprus, Israel, Somalia, and Mauritania have been omitted. Each chapter begins with a brief description of the country's location, political history, and broadcasting services (with some statistics), and then describes the history of its radio and television broadcasting development. Discussion is divided into radio and television. Information is offered about broadcasting history, series, programs, networks, and language. This information is often quite extensive, although some of the smaller and poorer nations have little to include. With the exception of the three chapters on North Africa, all chapters were written by Boyd, a communications professor at the University of Kentucky. The final part focuses on the introduction of radio and television broadcasting to the Arab world and the problems that they face. The 24-page bibliography includes a very wide range of materials, most in English. This is a primary source of information and another edition is probably in the works, or should be.

\section{4:153}

\section{A RECORD OF BIAS: NATIONAL PUBLIC RADIO'S COVERAGE OF THE ARAB-ISRAELI CONFLICT: SEPTEMBER 26-NOVEMBER 26, 2000}

by the Committee for Accuracy in Middle East Reporting (Boston: CAMERA "Monograph Series," 2001-\$9.95, ISBN 0-9661548-1-9, paper, 32 pp., charts, photographs) is a publication of the group (founded in 1992) whose purpose is to "promote more accurate, balanced and complete 
coverage of Israel and the Middle East." This non-scholarly work analyzes and describes the coverage of the Arab-Israeli conflict during a finite one-month period from September

26-November 26, 2000. Rightly or wrongly, many people in the United States are convinced that NPR's coverage of this situation is heavily weighted in favor of a pro-Palestinian stance and thus, as stated by the publication, "NPR has an Israeli problem"; it contends that the NPR is "marked by a striking anti-Israel tilt with severe bias, error, and lack of balance." It provides both examples and statistics to support this statement by analyzing the number of Arab and pro-Arab speakers and the airtime they have been given versus other speakers on the subject. These have been divided into chapters concerned with both quantitative and qualitative biases. Other findings include the more frequent use of pejorative language applied to Israelis. In all, the small association pamphlet includes seven chapters that also examine what it terms factual errors, one-sided segments, distortion, and concealment as well as the omission of key stories. Black and white photographs of individuals and events appear throughout the text. The publication concludes with full-text transcripts of All Things Considered and Morning Edition that serve to illustrate the contention of bias by CAMERA.

\section{4:154}

MEDIA RELATIONS HANDBOOK FOR MUSLIM ACTIVISTS by the Council on American-Islamic Relations (Washington: Council on American-Islamic Relations, 1996 - \$11.95, OCLC 43489739, 71 pp., photographs, appendix, newspaper reproductions; also available at ) supports the purpose of its publisher, CAIR, which is "to promote a positive image of Islam and Muslims in America." The association believes that this is necessary in part because Muslims are reluctant to articulate their cause. This slim publication is just one of CAIR's publications. It is somewhat unique in that it is essentially a workbook that seeks to instill a desire in the American Muslim community to become spokespersons to their local news organizations and to provide some skills that would be useful to that end. Included are sample press statements, useful information about Islam in America, such as how to make contacts, and a great deal of practical advice on meeting with press officials, staging media events, handling an interview, and even how to wear makeup and relax. Additional features include a list of relevant Internet sources and Muslim media outlets. About half of the booklet is devoted to full-page reproductions of news from various newspapers that represent positive coverage. Although non-scholarly in purpose and content, this warrants a place in a comprehensive journalism collection.

\section{4:155}

\section{QUESTIONS AND ANSWERS ABOUT ARAB AMERICANS: A JOURNALISTS} GUIDE by the Detroit Free Press (Detroit: Knight-Ridder, 2000-price not given, paper, 23 pp., bibliography, organization and web site lists; also available at ), while not a scholarly publication, is of reference value to both working journalists and journalism library collections for its brief but very useful and practical tips on working with and providing coverage of Arabs and Arab Americans in the United States. Although it focuses on coverage and information about this population in the Detroit area, by extension it can be applied to the Arab population in other areas of the United States as well. In one or two paragraphs it provides answers and information on a definition of Arab Americans, where they live, religious affiliations (many are Christian), languages, and a bit about the effect of the Middle East conflicts, mostly the Arab-Israeli conflict. Other sections describe such subjects as origins, clothing, politics, stereotypes, terminology, superstitions, and coverage. The publication also includes information and lists such as resources, 
organizations, and web sites. The publishers note that it will be updated frequently. This simple and easily accessible source should be available in all journalism collections.

\section{$34: 156$}

AL-JAZEERA: HOW THE FREE ARAB NEWS NETWORK SCOOPED THE WORLD AND CHANGED THE MIDDLE EAST by Mohammed el-Nawawy and Adel Iskander (Cambridge, MA: Westview Press, 2002-\$36.50, ISBN 0-8133-4017-9, 228 pp., photographs, notes, references, index) describes and assesses what is now one of the most frequently mentioned television networks outside the United States. Its actions, such as releasing its exclusive tapes of Bin Laden and his followers, have profoundly influenced our own politics and opinions and that of other nations. The two authors (both of whom are Arab emigrants) who are professors of journalism and communication at the universities of West Florida and Kentucky, respectively, provide a highly positive but not necessarily unbiased account of the history, background, particularly the influence of Al-Jazeera. They declare that it "has become part and parcel of the Arab world. It speaks to and for it." Of particular interest is their explanation of the network's impact on the Middle East as well as their good descriptions and analysis of specific programs. One of its eight chapters is devoted to a detailed description of its talk shows. Another examines its love-hate relationship with the world. Also relevant is their description of the relationship of this Qatar-based network with other Arab governments. The authors present a clear and unapologetic anti-Israeli bias throughout.

\section{4:157}

\section{FREE PRESS, FAIR PRESS: 1998 MIDDLE EAST MEDIA FORUM, JERUSALEM,} ISRAEL, SEPTEMBER 10; CAIRO, EGYPT, SEPTEMBER 14

by the Freedom Forum (Arlington, VA: Freedom Forum World Center, 1998 - no price given, 44 pp., photographs) is a highly relevant account of two separate but cohesive panel discussions held in Cairo and Jerusalem in September 1998. Each was convened to talk candidly about Palestinian, Egyptian, Israeli, and western press coverage while emphasizing the idea of press freedoms and fairness. Surrounded by photographs taken during the conferences, the full-text of the panel of experts are included. In all, the 11 sessions cover such topics as the need for more skills by Egyptian journalists, the lack of a tradition of public service by the Palestinian and other Arab media, the role of media conglomerates in the suppression of freedom of speech, the use of stereotyping by both Israeli and Palestinian media, and questions about the freedom and fairness of the Israeli press. The panelists included many very important representatives of the media from around the world. Included were an Israeli newspaper editorial writer, a correspondent from the Dallas Morning News, a managing editor of an Egyptian newspaper, a newspaper publishing chairman, a foreign editor of a Middle Eastern news weekly, and many others. A brief biographical description of each participant is included. Although not scholarly, this small publication does offer a great deal of honest commentary enhanced by the full-text discussion proceedings.

\section{4:158}

\section{THE WEST AND ISLAM IN THE MASS MEDIA: CORNERSTONES FOR A NEW} INTERNATIONAL CULTURE OF COMMUNICATION IN THE 21ST CENTURY by Kai Hafez (Bonn: Zentrum fur Europaische Integrationsforschung "ZEI Discussion Paper, C61," 2000 - price not given, paper, ISBN 3-9333-0761-9, 22 pp. bibliography) is a well-written, thoughtful document from the Center for European Integration Studies of the Rheinische 
Freidrich-Wilhelms University in Bonn, Germany. It is part of a series of discussion papers. Hafez, who is also the author or editor of the next two publications in this survey presents his thoughts and analysis in the form of a long essay. His central thesis is that "the media portray many errors or one-sided images that represent the West in the Islamic world and the Islamic world in the west." To support this statement he provides his narrative explanations and examples divided into such categories as symptoms, causes, consequences, and remedies. The essay represents one quite knowledgeable man's opinions and research with no accompanying notes. The slim, paper publication concludes with a bibliography of both German and English language books.

\section{4:159}

ISLAM AND THE WEST IN THE MASS MEDIA: FRAGMENTED IMAGES IN A GLOBALIZING WORLD edited by Kai Hafez (Cresskill, NJ: Hampton Press, 2000 — \$65.00/26.50, ISBN 1-57273-267-9 hard, ISBN 1-57273-268-7 paper, 299 pp., notes, references, charts, tables) is an anthology of 13 essays contributed by an international array of researchers, academics, and political advisors from such countries as Egypt, Germany, the United States, England, and Lebanon. Hafez is a member of the German Institute for Middle East Studies and the Institute for Political Science of the University of Hamburg. In addition to the editor, there are 14 other essayists; many of these are German scholars. The writings are arranged in four parts; Islam and the West in the mass media: general and theoretical studies; Islam and the West in the mass media: empirical country studies; the politics of Islam: reconsidering western perceptions, and can this image be saved? changing media images. Each is divided into two or more essays around its general theme. Essayists explore such topics as an analysis of British newspaper coverage of Islam, a similar analysis of the German press, the image of Islamic fundamentalism in the western media, the portrayal of Arab-Americans, and the western perception of the Middle East. It is particularly interesting since the authors provide a good analysis of not just the western media's perspective on Islam but Middle East journalistic coverage of the west as well. Each essay reflects credible and serious scholarship. A bibliography of works in English, German, and French follows each essay (some entries include Arabic and Farsi titles).

34:160

MASS MEDIA, POLITICS, AND SOCIETY IN THE MIDDLE EAST edited by Kai Hafez (Cresskill, NJ: Hampton Press “The Hampton Press Communication Series," 2001—\$26.50, paper, ISBN 1-5723-304-7, 378 pp., tables, bibliography, notes, index) focuses entirely on a wide range of issues relating to mass media and society in the Middle East. The author, an associate research fellow at the German Institute for Middle East Studies in Hamburg, Germany, pulls together ten essays by a number of international communication scholars on an equally wide range of media. These include television, the Internet, book production and publishing, and print media. Many of the scholars appear to be from the country about which they write while other contributors are academics working mostly in the United States, Germany, and France. The essays are divided into three parts: media control and ownership, mass media and development, and media and culture. Four of the chapters are devoted to discussion of the media in the Arab world in which that world is seen as a more or less cohesive whole. These chapters include an overview of the state of the mass media and its choice of diversification and stagnation, how Arab communications must adapt to the Information Age, the uses and adaptations of the Internet in the Arab world, and a perspective on the flow of information. Other chapters deal with various media in one or more countries of the Middle East including Egypt, Lebanon, Iran, Pakistan, and Saudi 
Arabia. The contributors investigate freedom of the press in Jordan between 1927 - 1988, the position of the government of Egypt regarding television production and availability, and, very interestingly, a description of the use of women of the media in a Cairo Islamic group. Each chapter concludes with its own list of resources that include English, French, German, Arabic, and other language publications. Ten pages of charts depict a summary of Jordanian press laws, a list of electronic publications, the level of press restrictions in Arab countries, and a dateline on the introduction of copyright laws in Arab countries. This scholarly publication seems to have included very well chosen and representative discussions of interest to other researchers on this topic, beginning with editor Hafez who is the author of hundreds of articles about Islam and the mass media. Each of the writings is well researched and offers very scholarly analysis.

\section{4:161}

U.S. MEDIA AND THE MIDDLE EAST: IMAGE AND PERCEPTION edited by Yahya R. Kamalipour (Westport: Greenwood Press "Contributions to the Study of Mass Media and Communications No. 46,” 1997-\$59.95/23.95, ISBN 0-313-29279-5 hard, 0-275-95914-7 paper, $242 \mathrm{pp}$., tables, figures, references, bibliography) presents the research of 24 contributors, all of whom are affiliated with American universities in a variety of areas of scholarship including journalism, communications, international relations, and others. The text appears in six parts: introductory perspectives; U.S. media and the Middle East: a general perspective; U.S. media and the Persian Gulf War; U.S. media and the Middle East: newspapers and magazines; electronic media and the Middle East; and media impact and perception. Each of the 18 essays addresses various aspects of how the U.S. media portrays the people, their beliefs, their leadership through an analysis of media news accounts, press photographs, political cartoons, news magazines, and motion pictures. Among those whose essays are represented are such recognized scholars in this area as Hamid Mowlana and Hamid Naficy. Among the media under discussion are press photographs, newspaper political cartoons, newsmagazines, and motion pictures. The essayists cover such pertinent issues as the depiction of use of Middle Easterners to depict terrorists in so many Hollywood movies, the impact of Arab images in political cartoons on American students, the portrayal of post revolutionary Iran in the media, and how Turks are depicted in major newsmagazines. Among other writings of interest is one that investigates the potential impact of such media imagery on young children, and two chapters concerning the Persian Gulf crisis and its resultant media images in the United States. The wide range of topics and their well-written delivery makes this a must for all media collections.

\section{4:162}

ISLAMIC PERIL: MEDIA AND GLOBAL VIOLENCE by Karim H. Karim (Montreal and London: Black Rose, 2000 - no prices given, ISBN 1-55164-173-9 hard, 1-55164-172-0 paper, $272 \mathrm{pp}$., illustrations, notes, tables, index) is a record of Karim's investigation of western media journalist's headlines and news stories related to the Middle East and other areas of the world with Muslim populations. Karim is an assistant professor at the school of journalism and communication at Carleton University in Ottawa. Prior to this appointment he was a working journalist for two European-based news services. He argues that western journalists in the United States and Europe adhere to a common belief that promotes "the spectre of the violent Islamic terrorist." The text is divided into ten chapters that focus on such themes as violence and the media, images of assassins, kidnappers and hostages, reporting from the Gulf War, and the meaning of jihad. Chapter 10, "Towards informed and conscientious reporting," is the author's 
challenge to western journalists to recognize that there are meaningful differences among Muslims and to reexamine their "dominant discourse" concerning Islam and violence. He also states that Muslims themselves bear part of the blame for this since they have failed to understand their own history and "societal failures." The author provides an interesting and scholarly perspective that takes full advantage of his journalistic and educational experiences. Of particular interest is his coverage of Muslim conflicts in such places as former Communist countries and the Balkans. Its recent publication and very relevant topics make this book a valuable addition to the field.

\section{4:163}

GOD HAS NINETY-NINE NAMES: REPORTING FROM A MILITANT MIDDLE EAST by Judith Miller (New York: Simon \& Schuster, 1996 - \$15.00, ISBN 0-684-83228-3, 574 pp., maps, notes, index) is based on the author's observations while a reporter in the Middle East since 1977 for The New York Times. During the Gulf War she was the newspaper's special correspondent. This is a non-scholarly but disturbing account from someone who has been on the scene since 1971. The title refers to God's 99 different names in the Koran. This first hand report is focused on the growth of militants and militant movements in Islamic countries as well as the impact this has on development and modernity. She provides historical, social, economic, and political contexts around which she develops her observations. She finds that the roots, causes, and militant events and experiences differ widely from country to country. Thus, her narratives are arranged into ten geographical chapters or sections. Included are Egypt, Saudi Arabia, Sudan, Algeria, Libya, Lebanon, Syria, Jordan, Israel, and Iran. Although her notes that accompany the text are often quite extensive, most of her commentary is drawn from her travels and experiences over a long career in the region. Miller's findings about the level of hate in the militants and the rapid spread of this movement are both awakening and frightening.

\section{4:164}

\section{REPORTING ISLAM: MEDIA REPRESENTATIONS AND BRITISH MUSLIMS by}

Elizabeth Poole (London and New York: I.B. Tauris, 2002—\$59.50/19.95, ISBN 1-86064-686-7 hard, ISBN 1-86064-687-5 paper, 240 pp., appendices, references, index, glossary, table, figures, notes, photographs) provides a critical and scholarly examination of the coverage of British Muslims in two major British newspapers, The Times and The Guardian. In her preface, the author explains that she was about to go to press with her book but September 11 led her to re-evaluate her research to see if it was relevant. This preface includes new findings by examining these two exceptionally important and influential British newspapers. In four chapters she presents a textual and quantitative analysis of articles devoted to British Muslims. Much of the information is contained in 29 tables which accompany the text that explore such topics as race relations, freedom of speech, the Rushdie affair, education, and other themes related to Islam. The four appendices include a glossary of terms, a list of themes and meaning of British Islam, a tabulated description of the focus group participants who took place in the study, and, finally, a list of relevant significant topics of 1999 related in the newspapers. Some commentary related to other newspapers is also included in the text. Since most of the sources available in English seem to be mostly or entirely devoted to the press of the United States and American Muslims, this book fills an important and missing element in the literature of Muslims and media. 


\section{$34: 165$}

COVERING ISLAM: HOW THE MEDIA AND THE EXPERTS DETERMINE HOW WE SEE THE REST OF THE WORLD by Edward W. Said (New York: Vintage Books, 1997 [rev. ed, 1st Vintage Books ed.]—\$19.95, paper, ISBN 0-679-75890-9, 200 pp., notes, index) contains Said's arguments in favor of his contention that "American and other western media offer highly stereotypical and belligerent views of Islam and its followers." He does acknowledge that there have been "many provocative and troubling incidents" by Muslims in such Islamic countries as Iran, Iraq, and Libya. Most of the text was written and released in 1981. This 1997 revised edition for the paperback edition features a new introduction and some other updates and changes. The text is divided into three parts: Islam as news, the Iran story, and knowledge and power. Each part is in turn divided into from one to four chapters. His most cogent argument is that one must not think of Islam and its people as monolithic. Included are the author's political and critical analyses of specific motion pictures, magazine articles, books, news broadcasts, newspaper articles, and documentaries. Said, a noted author and scholar, presents a serious and scholarly analysis of the media's handling of the region, its people, Iran, and the Israeli-Palestinian situation. He offers an historical context that always reveals his own religious and political opinions.

\section{$34: 166$}

\section{BLACK SEPTEMBER TO DESERT STORM: A JOURNALIST IN THE MIDDLE} EAST by Claude Salhani (Columbia: University of Missouri Press, 1998 — \$19.95, paper, ISBN 0-8262-1160-7, 262 pp., photographs, index) provides the personal reflections and adventures, some quite frightening, of journalist Claude Salhani, an American photojournalist and reporter who was associated with UPI for over 20 years covering wars, political events, and other history-making occasions in the Middle East and other Muslim lands. He has been at the scene of the Iranian Revolution, Desert Storm, and other momentous events. He documents these events and other such interesting times such as his travels with Henry Kissinger. While always quite fascinating, he provides insight into issues and events in which he has personally participated. He devotes a great deal of his narrative to the impact of religious extremism in one country after another as well as the issue of refugees. His book includes 18 chapters, many on specific countries including Cyprus, Saudi Arabia, Yemen, Egypt, Iran, Oman, and Israel. While he doesn't romanticize the dangers he faces, he does offer a fine and almost certainly realistic idea of what it is like to be a journalist on the scene, and often to some degree as a participant. While his is the life many budding journalists can only dream about, his perspective on his work is revealed in his concluding comment: "Journalism is a strange way to make a living, but what a great way to live." His own black-and-white photographs of his travels through the Middle East appear throughout the text. In all, a worthy read for those who seek adventure in journalism.

\section{$34: 167$}

ARAB AND MUSLIM STEREOTYPING IN AMERICAN POPULAR CULTURE by Jack G. Shaheen. (Washington: Center for Muslim-Christian Understanding, History and International Affairs, Edmund A. Walsh School of Foreign Service, Georgetown University's "Occasional Paper Series," 1997-\$5.95, paper, ISBN 1-929218-00-1, 91 pp., bibliography, notes) is one of about 300-plus publications by this noted author and frequent media commentator on the issue of the depiction of Arabs and Muslims in the media. This relatively slim university publication concentrates his analysis and descriptions of specific incidents of Arab and Muslim stereotyping in specific television, motion pictures, or print journalism sources. The text is divided into four parts. 
In addition to a thoughtful introduction, part II offers descriptions of specific examples of such stereotypical depictions in television and the movies, and part III is devoted to stereotypical depictions in print and broadcast news. Part IV on contesting the stereotype, is particularly valuable since Shaheen offers suggestions on how the media might provide a much needed balance of coverage. All of the examples are from the American media. Shaheen is an expert on this subject and picks the most appropriate samples. In addition, his words are clear, interesting, and highly relevant. Although he is obviously deeply annoyed and bothered by the unpleasant and often insulting and sometimes vile portrayals he describes, he leaves inflammatory rhetoric to others. This is a must for all communication collections.

\section{4:168}

ISLAM, MUSLIMS AND MEDIA: MYTHS AND REALITIES by Mohammed Ahmadullah Siddiqi (Chicago: American Association of Muslim Professionals and Scholars Publications, 1997-\$20.00, ISBN 0-6941624-1-5, paper, 182 pp., drawings, appendices, reproductions, references, index) provides research on the media coverage of Islam and Muslim Americans from the 1990s. Author Siddiqi is a professor of journalism and public relations at Western Reserve University; however, he is also affiliated with the American Islamic College and is an officer of the parent group of the publisher. He is also associated with the Islamic Circle of North America. Both his teaching and association activities make him highly qualified to address the issue of the media portrayal of Muslims and of Islam. The text, one-third of which is composed of various appendices, is divided into six chapters and an introduction. Only chapters one-through-three focus exclusively on the media and its portrayal of Islam and Muslims. Chapter 1, "Historical Overview," presents an historical review and analysis of such media portrayals including specific examples from American newspapers and television broadcasts. Chapters 2 and 3, titled respectively "Islam and Media" and "Muslims and Media," continue the same. The last three chapters offer information on the basic principles, beliefs, language, and traditions of Islam as well as a descriptive profile of Muslims living in the United States. Siddiqi proposes five steps that can lead to a better and more productive relationship between the media and American Muslims. The 13 appendices offer much useful and practical information on press releases, media kits, media directories, associations, and some examples of real coverage that has been effective and positive.

\section{4:169}

MEDIA AND POLITICAL CONFLICT: NEWS FROM THE MIDDLE EAST by Gadi Wolfsfeld (Cambridge and New York: Cambridge University Press, 1997— \$65.00/24.00, ISBN 0-521-58045-5 hard, ISBN 0-521-5896-7-3 paper, 255 pp., figures, tables, appendix, notes, references, index) is divided into three parts, each including several chapters which in some way examines the role of the mass media in the conflict. The research provides a theoretical model using case studies to illustrate "the ways news media do and do not become, active participants in the conflict." Part I, the rules of combat, offers a more general explanation of the influence of the political environment on the media and the influence of the media on the political environment. Part II, the contests, is composed of case studies which address such issues as the Oslo Accords, the Intifada, and the Gulf War. Part III offers a conclusion. A professor at the Hebrew University in Jerusalem, Wolfsfeld's overarching theme behind each event and case study is the struggle of the political movements for media access. Each case study provides examples of how the events are covered in the Israeli newspapers. Chapter 8, "The Cultural Struggle over the Gulf War: Iraqi 
Aggression or American Imperialism?" is particularly important as it suggests some insight and context into the current Iraqi situation. 